\title{
Aplikasi Krioprotektan Ekstraseluler Tunggal Secara Efektif Mempertahankan Kualitas Sperma Manusia Pascavitrifikasi
}

\author{
Rini Widyastuti, ${ }^{1,2}$ Mohammad Ghozali, ${ }^{3}$ Mas Rizky A. A Syamsunarno ${ }^{2,3}$ \\ ${ }^{1}$ Laboratorium Reproduksi dan Inseminasi Buatan, Departemen Produksi Ternak, Fakultas Peternakan, \\ Universitas Padjadjaran Bandung, Indonesia, ${ }^{2}$ Laboratorium Sentral, Universitas Padjadjaran Bandung, \\ Indonesia, ${ }^{3}$ Departemen Ilmu Kedokteran Dasar Fakultas Kedokteran Universitas Padjadjaran Bandung, \\ Indonesia
}

\begin{abstract}
Abstrak
Pemilihan jenis krioprotektan merupakan salah satu kunci keberhasilan dalam mempertahankan motilitas dan viabilitas sperma pascavitrifikasi. Secara konvensional, vitrifikasi menggunakan konsentrasi krioprotektan dan laju kecepatan pembekuan yang tinggi untuk menghindari pembentukan kristal es intra dan ekstraseluler yang menyebabkan kerusakan dan kematian pada sel. Berdasar atas kemampuan menembus membran sel, krioprotektan dibedakan menjadi krioprotektan ekstra dan intraseluler. Sperma manusia memiliki struktur morfologi yang sangat padat dan sedikit mengandung sitoplasma sehingga perpindahan cairan selama proses vitrifkasi sangat kecil. Selain itu, sperma manusia juga mengandung beberapa jenis protein yang dapat berfungsi sebagai krioprotektan intraseluler. Berdasar atas kondisi tersebut, penggunaan krioprotektan pada vitrifkasi sperma manusia memerlukan studi lebih lanjut. Penelitian ini dilakukan di Laboratorium Sentral Universitas Padjadjaran dan dilaksanakan pada bulan Desember 2017-Januari 2018. Penelitian ini bertujuan mengetahui motilitas dan viabilitas sperma pascavitrifikasi dengan menggunakan tipe krioprotektan yang berbeda dan kombinasi keduanya. Earle's balanced salt solution digunakan sebagai krioprotekan ekstraseluler, sementara EG 0,57\% sebagai krioprotektan intraseluler. Sampel yang telah ditambahkan medium vitrifikasi diequilibrasi selama 10 menit, kemudian dikemas di dalam straw 0,25 mL dan langsung dipaparkan ke dalam nitrogen cair. Evaluasi dilakukan dengan melakukan thawing setelah 24 jam penyimpanan. Hasil menunjukkan bahwa motilitas dan viabilitas sperma tertinggi pada kelompok yang menggunakan media vitrifikasi krioprotektan ekstraseluler, walaupun secara statistik tidak berbeda nyata dengan kelompok lainnya $(34 \% ; 50 \% ; p<0,05)$. Sebagai simpulan, krioprotektan ekstraseluler merupakan media vitrifikasi terbaik untuk menjaga motilitas dan viabilitas sperma pascavitrifikasi
\end{abstract}

Kata kunci: Krioprotektan, sperma manusia, vitrifikasi

\section{Single Extracellular Cryoprotectant Application Effectively Maintain Post- Vitrification Human Sperm Quality}

\begin{abstract}
Selection of cryoprotectant is one of the keys to maintain sperm motility and viability after vitrification. Conventionally, vitrification uses cryoprotectants with high concentration and cooling rate to avoid the formation of intra- and extra-cellular ice crystals that can induce cell damage and cell death. Morphology structure of human sperm is very dense and contain less cytoplasm compartment; therefore mobilization of fluid is minimum during vitrification. In addition, human sperm also contains several types of protein that function as intracellular cryoprotectants. Based on this condition, the use of cryoprotectants in human sperm vitrification needs a further study. This study was conducted at the Central Laboratory of Universitas Padjadjaran in December 2017-January 2018. The aim was to determine the motility and viability of post-vitrification sperm by using different types of cryoprotectants. Samples that had been mixed with vitrification medium were equilibrated for 10 minutes, packed in a $0.25 \mathrm{~mL}$ straw, and directly exposed to liquid nitrogen. The evaluation was conducted by thawing after 24 hours of storage. The results showed that the highest sperm motility and viability was found in the group that used extracellular cryoprotectant vitrification media although it was not statistically different ( $34 \%$; $50 \%$, p $<0.05$ ) In conclusion, extracellular cryoprotectants are the best vitrification medium for maintaining motility and viability of post-vitrification sperm.
\end{abstract}

Key words: Cryoprotectant, sperm, vitrification

Korespondensi: Rini Widyastuti, drh., M.Si, Laboratorium Reproduksi dan Inseminasi Buatan, Departemen Produksi Ternak, Fakultas Peternakan Universitas Padjadjaran, Jalan Raya Bandung Sumedang KM 21, Jatinangor 45363, Email: r.widyastuti@ unpad.ac.id 


\section{Pendahuluan}

Kriopreservasi sperma sudah diaplikasikan dalam teknologi reproduksi berbantu (TRB) sebagai prosedur standar untuk menyimpan sperma sebelum dilakukan inseminasi intra uteri (IIU) atau fertilisasi in vitro (FIV). Hal utama yang menjadi perhatian pada kriopreservasi sperma adalah dapat meminimalisir kerusakan sel dan meningkatkan tingkat kelangsungan hidup dari sel yang telah dibekukan. ${ }^{1}$ Upaya untuk mencapai hal tersebut adalah dengan menggunakan berbagai macam peralatan dan media yang digunakan untuk pembekuan. Isu yang cukup menarik kriopreservasi sperma pada TRB di manusia adalah dengan mengembangkan protokol yang juga efektif untuk pembekuan sehingga dapat meminimalisir kerusakan yang terjadi selama proses pembekuan dan pencairan (thawing).

Sampai saat ini metode kriopreservasi sperma yang umum diterapkan adalah metode konvensional slow freezing cryopreservation. Kelemahan metode ini adalah pembentukan kristal es intraseluler yang berpotensi merusak membran dan organel sel, serta memerlukan waktu yang lama dan peralatan yang mahal. ${ }^{2}$ Metode alternatif untuk kriopreservasi sperma adalah vitrifikasi. Metode vitrifikasi lebih efektif, cepat, sederhana, dan lebih murah karena tidak memerlukan penggunaan alat program pembekuan. Keuntungan lain metode vitrifikasi ini adalah mampu menghindari pembentukan kristal es intra maupun ekstraseluler yang berpotensi merusak sel. ${ }^{3}$ Kondisi demikian terjadi oleh karena pada vitrifikasi pemadatan cairan terjadi melalui peningkatan viskositas yang ekstrim dengan laju pendinginan yang sangat cepat. ${ }^{4}$ Konsekuensi meminimalisir pembentukan kristal es tadi adalah menggunakan krioprotektan dengan konsentrasi tinggi yang dapat menimbulkan efek toksik ${ }^{5}$ dan kejutan osmotik sehingga akan menurunkan kecepatan pemulihan sperma pascavitrifikasi. ${ }^{6}$

Krioprotektan merupakan zat kimia yang berfungsi melindungi sel dari efek negatif atau letal pada saat proses pendinginan maupun proses pembekuan. Berdasar atas sifat fisikakimia dan permeabilitas terhadap membran sel, krioprotektan dibedakan menjadi krioprotektan intraseluler dan ekstraseluler. Krioprotektan ekstraseluler mempunyai ukuran molekul yang cukup besar sehingga tidak mampu melewati membran sel dan juga berperan penting dalam menjaga integritas membran sel pada saat proses dehidrasi berlangsung. Krioprotektan intraseluler memiliki ukuran yang sangat kecil sehingga dapat berdifusi masuk ke dalam sel dan berperan sebagai bufer cairan intraseluler dan meminimalkan kerusakan sel pada saat proses pembekuan. $^{7}$

Beberapa studi telah dilakukan untuk dapat mengkaji optimasi penggunaan krioprotektan pada vitrifikasi sperma manusia dengan cara penambahan serum dan sukrosa ke dalam media dasar, ${ }^{8}$ gliserol, $^{6}$ kombinasi etilen glikol dan sukrosa dengan konsentrasi secara bertingkat ${ }^{9}$ dan tanpa krioprotektan. ${ }^{10,11}$ Namun demikian, kecepatan pemulihan sperma pascavitrifikasi dari penelitian-penelitian tersebut masih sangat bervariasi.

Sperma manusia memiliki struktur anatomi yang padat dan kandungan sitoplasma sangat sedikit. Kondisi yang demikian menyebabkan perpindahan cairan pada saat proses dehidrasi dan rehidrasi sangat kecil. Selain itu, sperma manusia yang mengandung protein, gula, dan juga komponen lain yang membuat matriks intraseluler mempunyai viskositas tinggi. ${ }^{11}$ Keberadaan protein tersebut dapat berfungsi sebagai krioprotektan intraseluler yang alami bagi sperma. Secara alamiah, krioprotektan intraseluler akan melindungi sel pada saat proses pembekuan. Namun demikian, penggunaan krioprotektan intraseluler secara tunggal dapat menimbulkan efek tosik yang menyebabkan kematian pada sel.

Penggunaan krioprotektan pada vitrifikasi sperma manusia perlu dikaji lebih lanjut. apakah memerlukan kombinasi krioprotektan intraseluler dan ekstraseluler, krioprotektan ekstraseluler saja, atau tanpa mempergunakan krioprotektan. Pada penelitian ini dilakukan kajian untuk membandingkan bagaimana recovery rate sperma pascavitrifikasi dengan menggunakan ketiga jenis kemungkinan, yaitu a) sperma dibekukan dengan menggunakan metode vitrifikasi; b) tanpa menggunakan krioprotektan; c) krioprotektan ekstraseluler; dan d) kombinasi krioprotektan intraseluler dengan ekstraseluler. Hasil dari penelitian ini diharapkan dapat dimanfaatkan sebagai metode alternatif kriopreservasi sperma untuk teknologi reproduksi berbantu (TRB) di klinik infertilitas.

\section{Metode}

Penelitian ini dilakukan di Laboratorium Sentral Universitas Padjadjaran. Penelitian dilaksanakan pada bulan Desember 2017-Januari 2018. Semua prosedur pada penelitian ini mengikuti 
tata cara dan syarat ketentuan berlaku di Fakultas Kedokteran Universitas Padjadjaran dengan Nomor Etik 1259/UN6.C.10/PN/2017.

Media bufer yang digunakan adalah Earle's balanced salt solution (EBSS) (Thermo fisher Scientific Cat. no 14155063, Germany). Jenis krioprotektan ekstraseluler yang digunakan adalah sukrosa (Sigma-Aldrich, Cat. no V900116, USA) dan human albumin serum (HAS) (Vitrolife, Sweden). Jenis krioprotektan intraseluler yang digunakan adalah ethylen glikol (Sigma-Aldric, Cat. No. 324558, USA).

Bahan penelitian yang digunakan adalah sperma yang berasal dari ejakulat 8 orang sukarelawan yang memeriksakan diri ke Klinik Fertilitas Melinda Hospital. Sebelum pengambilan sampel, sukarelawan diberikan penjelasan dan bagi yang bersedia memberikan sampelnya diminta untuk menandatangani persetujuan (informed consent). Semen dikoleksi setelah 2-7 hari abstinensia seksual dengan cara masturbasi dan ejakulat ditempatkan dalam kontainer steril yang tertutup rapat. Sampel dibiarkan selama 30 menit sampai 1 jam pada suhu ruang agar mencair (likuefaksi). Sampel yang diambil merupakan sisa yang sudah tidak digunakan dari sampel yang digunakan untuk pelayanan pemeriksaan sperma. Pada penelitian ini dilakukan tiga kali pengamatan motilitas dan juga viabilitas sperma, yaitu pada setiap tahapan vitrifikasi pada tahap ejakulat, ekuilibrasi, dan thawing. Pengamatan tahap ejakulat dilakukan untuk skrining sampel, tahap ekuilibrasi untuk mengevaluasi kondisi sperma setelah ditambahkan media vitrifikasi dan kondisi sebelum pembekuan, selanjutnya pada tahap thawing untuk mengevaluasi sperma pascavitrifikasi.

Ejakulat yang telah diperoleh dari sampel diuji kualitasnya secara mikroskopis untuk skrining sampel. Ejakulat yang dipergunakan pada penelitian ini adalah yang mempunyai konsentrasi lebih atau sama dengan 15 juta/mL, motilitas progresif lebih dari atau sama dengan $50 \%$, dan viabilitas lebih dari atau sama dengan $50 \%$. Evaluasi sampel tersebut dilakukan sesuai dengan prosedur standar yang tercantum dalam pedoman WHO tahun 2010. ${ }^{12}$

Pemisahan plasma semen dilakukan dengan cara sentrifugasi dengan kecepatan $600 \mathrm{~g}$ selama 10 menit. Pelet sperma ditambahkan media bufer, yaitu EBSS sebanyak 1,5 mL, kemudian dibagi menjadi 3 kelompok berdasar atas jenis kriopotektan yang digunakan: (i) EBSS + sukrosa 0,25\% + HAS 1\% + EG 0,57\% (ekstra dan intraseluler); (ii) EBSS + sukrosa 0,25\% +
HAS 1\% (ekstraseluler); dan (iii) EBSS (tanpa krioprotektan). Sperma yang telah dicampur dengan medium vitrifikasi diekuilibrasi selama 10 menit pada suhu ruang sambil dikemas ke dalam straw 0,25 $\mathrm{mL}$ dan ditutup dengan cara sealing menggunakan polyvynil alcohol (PVA). Selama ekuilibrasi, diambil contoh sampel untuk evaluasi viabilitas dan motilitas sperma. Sperma yang telah dikemas dalam straw diuapi di atas permukaan nitrogen cair selama 5 detik, kemudian langsung dimasukkan ke dalam nitrogen cair $-196{ }^{\circ} \mathrm{C}$. Setelah penyimpanan selama 24 jam, straw yang berisi semen yang telah divitrifikasi diambil dari nitrogen cair dan dilakukan proses thawing. Metode thawing yang dilakukan adalah dengan cara mengambil straw dari nitrogen cair dan diletakkan pada air $37^{\circ}$ C selama 5 detik. Straw diambil dan digunting ujung-ujungnya, selanjutnya setiap sampel dipindahkan ke dalam mikrotube 1,5 mL dan dilakukan pengamatan secara mikroskopis untuk melihat persentase motilitas dan viabilitas sperma setelah vitrifikasi. ${ }^{11}$

Pengamatan motilitas sperma dilakukan dengan cara menghitung jumlah sperma yang bergerak progresif dibanding dengan sperma yang tidak bergerak. Sebanyak $10 \mu \mathrm{L}$ sperma diteteskan pada kamar hitung Neubauer dan ditutup cover glass. Selanjutnya, sebanyak 200 sperma diamati, lalu dihitung persentase sperma yang bergerak. Persentase viabilitas sperma diamati memakai pewarnaan eosin-nigrosin. Preparat ulas dibuat dengan cara mencampur antara sampel sperma dan pewarna eosinnigrosin (1:1), kemudian dikeringkan. Sebanyak 200 sel sperma diamati di bawah mikroskop dengan perbesaran 20x10. Sperma viabil ditandai dengan warna pucat pada bagian kepala, sedangkan sperma nonviabil akan memberikan warna merah. Pada sperma yang telah mati, permeabilitas membran sel telah rusak sehingga senyawa kimia yang digunakan untuk pewarnaan bebas melewati membran plasma dan masuk ke dalam sel. Data yang diperoleh pada penelitian ini dianalisis sidik ragam (ANOVA), uji lanjut Tukey dengan perbedaan signifikan $\mathrm{p}<0,05$. Analisis dilakukan dengan menggunakan SPSS software version 16.0 (SPSS Inc, Chicago, IL, USA).

\section{Hasil}

Hasil pengukuran motilitas progresif dan viabilitas sperma pada setiap tahapan vitrifikasi disajikan pada Gambar 1 dan Gambar 2. Pada Gambar 1 dapat dilihat bahwa nilai persentase 


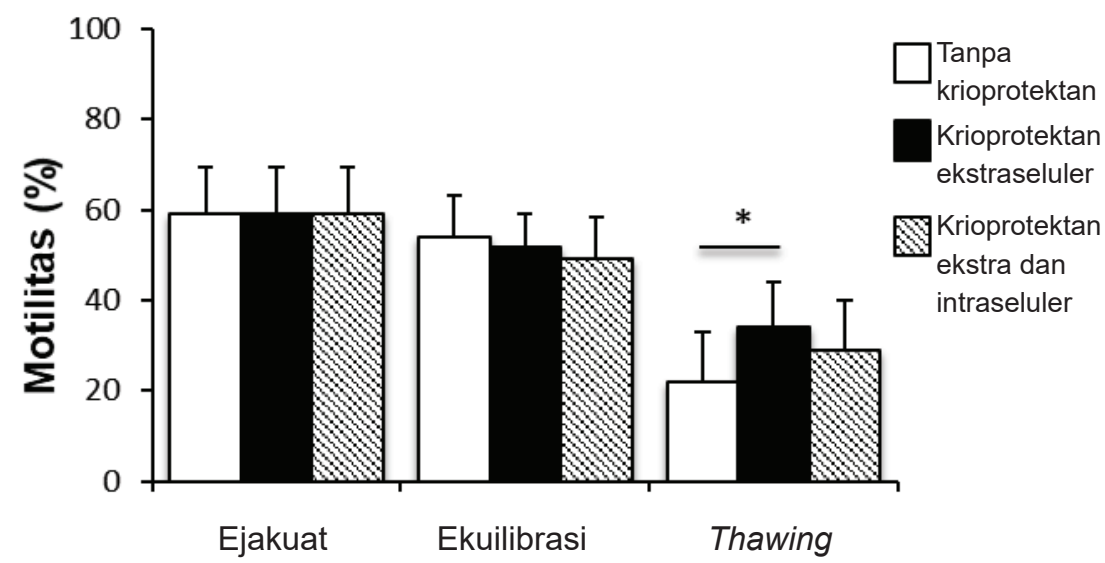

\section{Gambar 1 Motilitas Sperma pada Setiap Tahapan Vitrifikasi}

Motilitas sperma menurun pada setiap tahapan vitrifikasi. Motilitas sperma setelah thawing meningkat secara signifikan pada kelompok yang diberi krioprotektan ekstraseluler. ${ }^{*} \mathrm{p}<0.05$

motilitas sperma mengalami penurunan pada tahap ekuilibrasi dan setelah thawing. Pada tahap ekuilibrasi, penurunan motilitas sperma sekitar $10 \%$ dari tahap ejakulat. dan secara statistik tidak berbeda nyata antara ketiga kelompok perlakuan. Pada tahap thawing terjadi penurunan nilai persentase motilitas sperma.

Nilai persentase motilitas sperma pada kelompok yang sudah divitrifikasi menggunakan krioprotektan lebih apabila dibanding dengan kelompok sperma yang tanpa menggunakan krioprotektan. Pada kelompok yang vitrifikasi menggunakan krioprotektan ekstraelular adalah $34 \%$ pada kelompok sperma yang divitrifikasi dengan kombinasi krioprotektan ekstraseluler dan intraseluler adalah 28\%. Nilai persentase motilitas sperma terendah pada kelompok yang divitrifikasi tanpa menggunakan krioprotektan, yaitu $21 \%$. Nilai persentase motilitas sperma pasca-thawing pada kelompok yang dibekukan tanpa menggunakan krioprotektan dengan kedua kelompok yang menggunakan krioprotektan secara statistik berbeda nyata $(p<0,05)$.

Penurunan nilai persentase motilitas sperma pada tahap ekuilibrasi dan pasca-thawing diikuti oleh penurunan nilai persentase viabilitas sperma. Nilai persentase viabilitas sperma pada tahap ekuilibrasi dan tahap thawing secara

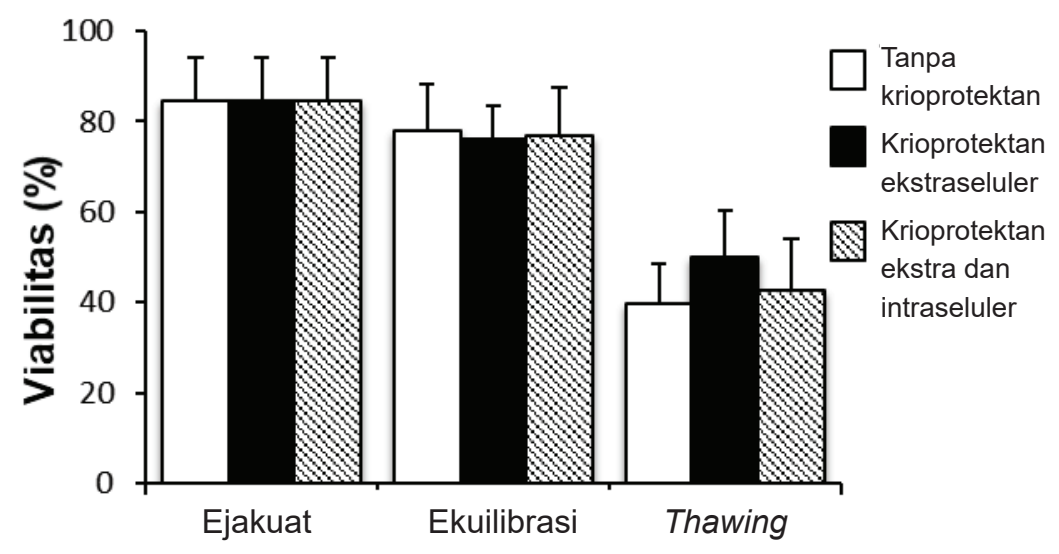

\section{Gambar 2 Viabilitas Sperma pada Setiap Tahapan Vitrifikasi. Viabilitas Sperma Menurun pada Setiap Tahapan Vitrifikasi}


statistik tidak berbeda nyata antara ketiga kelompok perlakuan. Namun demikian, nilai persentase viabilitas sperma yang tertinggi adalah pada kelompok yang menggunakan krioprotektan ekstraseluler dan nilai terendah pada kelompok sperma yang dibekukan tanpa menggunakan krioprotektan (Gambar 2).

\section{Pembahasan}

Pemilihan krioprotektan untuk pembekuan sperma juga didasarkan pada kemampuan krioprotektan untuk dapat menjaga integritas membran serta fungsi sperma selama dan setelah proses pembekuan. Efek yang paling penting krioprotektan adalah meminimalkan pembentukan kristal es dengan memindahkan air dari sitoplasma melalui efek osmotik atau bergabung dengan inti es dan tumbuh di dalam sitoplasma atau di ruang ekstraseluler yang mengelilingi sel. ${ }^{13}$

Motilitas progresif dan viabilitas sperma merupakan salah satu indikator utama dalam proses evaluasi sperma. Variabel ini sangat erat hubungannya dengan daya fertilisasi sperma baik secara in vivo maupun in vitro. Secara umum proses kriopreservasi akan menyebabkan penurunan nilai motilitas dan viabilitas sperma yang disebabkan oleh kerusakan organel. ${ }^{14}$ Kerusakan yang timbul dipicu oleh perubahan temperatur yang sangat drastis sehingga terjadi stres osmotis, dehidrasi seluler, stres oksidatif, kerusakan DNA, ketidakstabilan kromatin, dan kerusakan DNA sperma. ${ }^{15}$ Kondisi demikian akan menyebabkan kerusakan pada sperma. Beberapa kasus telah dilaporkan bahwa apabila FIV maupun IIU dilakukan dengan menggunakan sperma yang memiliki kualitas kurang baik maka akan meningkatkan risiko abortus karena kerusakan material genetik pada sperma. ${ }^{16}$

Hasil yang diperoleh pada penelitian ini menunjukkan bahwa vitrifikasi sperma dengan menggunakan kriprotektan hasil yang lebih baik apabila dibanding tanpa menggunakan krioprotektan. Krioprotektan berperan penting mereduksi pengaruh letal yang diakibatkan oleh osmotic shock maupun pembentukan kristal es intraseluler dan juga ekstraseluler pada saat proses vitrifikasi. Krioprotektan ekstraseluler yang berukuran besar dan tidak memiliki kemampuan untuk berdifusi ke dalam membran sel berperanan dalam menciptakan tekanan osmotik yang menginduksi dehidrasi sel dan mengurangi pembentukan kristal es. Krioprotektan intraseluler memiliki ukuran kecil sehingga mampu menembus membran sel dan berperan meminimalisir pembentukan kristal es dengan cara memindahkan air dari sitoplasma melalui efek osmotik. ${ }^{17}$

Hasil yang diperoleh pada penelitian ini telah menunjukkan bahwa vitrifikasi sperma manusia dengan menggunakan krioprotektan ekstraseluler menunjukkan hasil yang lebih baik bila dibanding dengan kombinasi antara krioprotektan ekstraseluler dan intraseluler. Kondisi demikian telah menunjukkan bahwa krioprotektan ekstraseluler lebih efektif dipergunakan untuk vitrifikasi pada sperma manusia. Hal ini berkaitan erat dengan struktur morfologi kepala sperma yang cukup padat dengan kandungan sitoplasma yang sangat sedikit. ${ }^{8}$ Struktur kepala sperma sangat padat dan kompak karena terdapat kromatin yang terdiri atas deoxyribo nucleat acid (DNA) dan protein-protein heterogen. DNA sperma manusia tersusun ke dalam loop yang melekat pada sisi spesifik dari matriks sperma. Loop ikatan DNA sperma ini terdiri atas protamin yang kaya akan kandungan arginin dan sistein untuk membentuk ikatan disulfid yang menjaga stabilitas dan kekompakan DNA sperma. ${ }^{18}$ Selain itu, kepala sperma manusia juga mengandung protein yang cukup kompleks. ${ }^{11}$ Keberadaan protein tersebut automatis akan meningkatkan viskositas di dalam sel sehingga secara alamiah dapat berfungsi sebagai krioprotektan intraseluler.

Struktur morfologi sperma manusia yang sangat padat dan kandungan protein yang kompleks dan sitoplasma yang sangat sedikit tersebut akan meminimalisir pembentukan kristal es intraseluler pada saat proses vitrifikasi berlangsung. Dengan demikian, penambahan kriopotektan intraseluler pada media vitrifikasi memiliki peranan yang kurang signifikan. Akan tetapi, penambahan krioprotektan ekstraseluler di dalam media vitrifikasi sangat diperlukan dan memiliki peranan yang sangat penting untuk menjaga stabilitas membran pada saat proses dehidrasi dan meminimalisir pembetukan kristal es ekstraseluler.

Penelitian ini krioprotektan ekstraseluler yang digunakan adalah sukrosa dan HAS. Sukrosa merupakan golongan gula yang tidak mampu berdifusi masuk melalui membran plasma. Dengan demikian, sukrosa akan menghasilkan tekanan osmotik yang menginduksi proses dehidrasi serta mengurangi pembentukan kristal es intraseluler. Sukrosa juga berinteraksi dengan pospolipid di dalam membran plasma, mereorganisasi membran sperma sehingga survive pada saat pembekuan. ${ }^{19}$ Penambahan 
sukrosa, HAS sebagai krioprotektan ekstraseluler dalam media vitrifikasi disertai dengan peningkatan laju kecepatan pembekuan akan meningkatkan viskositas media di sekeliling sel dan mencegah pembentukkan kristal es baik intraseluler maupun ekstraseluler. Pada penelitian sebelumnya juga disampaikan bahwa penggunaan sukrosa di dalam media vitrifikasi tanpa disertai penambahan krioprotektan intraseluler telah menghasilkan motilitas sperma yang tinggi setelah thawing dan secara efektif melindungi mitokondria dan membran sperma ${ }^{8}$ serta integritas DNA pasca-warming. ${ }^{8}$

Persentase motilitas progresif sperma hasil vitrifikasi dengan menggunakan krioprotektan ekstraseluler pada percobaan ini lebih rendah 15\% apabila dibanding dengan hasil peneliti sebelumnya yang menggunakan human tubal fluid (HTF) sebagai media bufer. ${ }^{8}$ Kondisi ini karena pada penelitian sebelumnya sampel yang digunakan hanya berasal dari sperma motil dari ejakulat yang telah dipreparasi dengan metode swim-up untuk memisahkan antara sperma yang motil dan immotile. Selain itu, ukuran sampel yang digunakan juga sangat kecil berupa pelet $0,5 \mu \mathrm{L}$ yang langsung dipaparkan ke dalam cairan nitrogen sehingga memiliki laju kecepatan pembekuan yang lebih tinggi apabila dibanding dengan sampel yang ditempatkan di dalam straw 0,5 mL. Namun demikian, penggunaan sampel dengan bentuk pelet akan menimbulkan kesulitan pada saat dilakukan thawing karena akan menginduksi penguapan yang ekstensif pada permukaan nitrogen cair. ${ }^{20}$

Berdasar atas hasil penelitian ini disimpulkan bahwa dengan menggunakan krioprotektan di dalam media vitrifikasi memberikan dampak yang lebih baik dan mampu mempertahankan motilitas dan viabilitas sperma pascavitrifikasi bila dibandingtanpamenggunakan krioprotektan Hasil penelitian ini dapat diaplikasikan simpan beku sperma untuk individu yang mempunyai konsentrasi sperma yang rendah maupun sperma yang berasal dari tindakan percutaneus epididymal sperm aspiration (PESA), testicular sperm aspiration (TESA), microsurgical epididymal sperm aspiration (MESA) maupun microsurgical testicular sperm extraction (MICROTESE) pada pelayanan TRB. Vitrifikasi sperma memungkinkan waktu pengerjaan yang cukup singkat dan biaya yang lebih murah apabila dibanding dengan aplikasi metode konvensional slow freezing sehingga akan lebih efektif dan efesien apabila diaplikasikan dalam pelayanan TRB.

\section{Daftar Pustaka}

1. Mocé E, Fajardo AJ, Graham JK. Human sperm cryopreservation. Eur Med J. 2016;1(1):869.

2. Di Santo M, Tarozzi N, Nadalini M, Borini A. Human sperm cryopreservation: update on techniques, effect on dna integrity, and implications for ART. Adv Urol. 2012;2012:14.

3. Kolibianakis EM, Venetis CA, Tarlatzis BC. Cryopreservation of human embryos by vitrification or slow freezing: which one is better?. Curr Opin Obstet Gynecol. 2009;21(3):270-4.

4. Curaba M, Verleysen M, Amorim CA, Dolmans MM, Van Langendonckt A, Hovatta O, dkk. Cryopreservation of prepubertal mouse testicular tissue by vitrification. Fertil Steril. 2011;95(4):1229-34.

5. Aye M, Di Giorgio C, De Mo M, Botta A, Perrin J, Courbiere B. Assessment of the genotoxicity of three cryoprotectants used for human oocyte vitrification: dimethyl sulfoxide, ethylene glycol and propylene glycol. Food Chem Toxicol. 2010;48(7):1905-12.

6. Saki G, Rahim F, Zergani MJ. Vitrification of small volume of normal human sperms: use of open pulled straw carrier. J Med Sci. 2009;9(1):30-5.

7. Motta JP, Paraguassu-Braga FH, Bouzas LF, Porto LC. Evaluation of intracellular and extracellular trehalose as a cryoprotectant of stem cells obtained from umbilical cord blood. Cryobiology. 2014;68(3):343-8.

8. Isachenko $\mathrm{E}$, Isachenko $\mathrm{V}$, Weiss JM, Kreienberg R, Katkov II, Schulz M, dkk. Acrosomal status and mitochondrial activity of human spermatozoa vitrified with sucrose. Reproduction. 2008;136(2):167-73.

9. Widyastuti R, Sumarsono SH, Boediono A, Rasad SD. Low concentration of ethylene glycol improve the recovery rate of human spermatozoa after vitrification. Jurnal Veteriner. 2016;17(3):1-7.

10. Isachenko V, Montag M, Isachenko E, Nawroth F, Dessole S, van der Ven H. Developmental rate and ultrastructure of vitrified human pronuclear oocytes after step-wise versus direct rehydration. Hum Reprod. 2004;19(3):660-5.

11. Widyastuti R, Lesmana R, Boediono A, Sumarsono SH. Effect of cryoprotectants on sperm vitrification. Advances in Biomolecular Medicine: Proceedings of the 4th BIBMC (Bandung International 
Biomolecular Medicine Conference) 2016 and the 2nd ACMM (ASEAN Congress on Medical Biotechnology and Molecular Biosciences), October 4-6, 2016, Bandung, West Java, Indonesia. CRC Press; 2017.

12. World Health Organisation. WHO laboratory manual for the examination of human semen and sperm-cervical mucus interaction. Cambridge: Cambridge University Press; 1999.

13. Vajta G, Kuwayama M. Improving cryopreservation systems. Theriogenology. 2006;65(1):236-44.

14. Boitrelle F, Albert M, Theillac C, Ferfouri F, Bergere M, Vialard F, dkk. Cryopreservation of human spermatozoa decreases the number of motile normal spermatozoa, induces nuclear vacualization and chromatin decondensation. J Androl. 2012;33(6): 1371-8.

15. Ribas-Maynou J, Fernandez-Encinas A, Garcia-Peiro A, Prada E, Abad C, Amengual MJ. Human semen cryopreservation: a sperm DNA fragmentation study with alkaline and neutral Comet assay. Andrology. 2014;2:837.
16. Petyim S, Neungton C, Thanaboonyawat I, Laokirkkiat P, Choavaratana R. Sperm preparation before freezing improves sperm motility and reduces apoptosis in postfreezing-thawing sperm compared with post-thawing sperm preparation. J Assist Reprod Genet. 2014;(12):1673-80.

17. Vanderzwalmen P, Connan D, Grobet L, Wirleitner B, Remy B, Vanderzwalmen S, dkk. Lower intracellular concentration of cryoprotectants after vitrification than after slow freezing despite exposure to higher concentration of cryoprotectant solutions. Hum Reprod. 2013;28(8):2101-10.

18. Shamsi MB, Kumar R, Dada R. Evaluation of nuclear DNA damage in human spermatozoa in men opting for assisted reproduction. Indian J Med Res. 2008;127(2):115-23.

19. BP Best. Cryoprotectant toxicity: facts, issues, and questions. Rejuvenation Res. 2015;18(5):422-36.

20. Hreinsson J. Vitrification in assisted reproduction. A users manual and troubleshooting guide. Acta Obstet Gynecol Scand. 2009;88(3):367-8. 